\title{
The Image of "Opening and Changing” Vietnam in Thai Contemporary Fiction Books
}

\author{
Tran Cam Tu (เจิ่น เกิ๋ม ตู๊) \\ PhD in Thai Studies, Chulalongkorn University, Bangkok, Thailand \\ trancamtu.thephin@gmail.com
}

\begin{abstract}
As Thailand and Vietnam have long had mutual relations, there are a number of Thai books written about Vietnam, including academic and historical documents, travelogues, novels, and short stories. This paper examines works of contemporary Thai fiction to present a new and outstanding image of Vietnam in a Thai perception - an "opening and changing" country - from factual data and from literary textual analysis. First, it provides readers with the socio-historical background of the Renovation Era of Vietnam after 1986 and the Thai-Vietnamese relationship. Next, the main part explains how the image of "opening and changing" Vietnam is portrayed through four aspects: (1) physical changes in landscape, cityscape, and economic development; (2) changes in lifestyle and traditions; (3) openness in political views and international relations; and (4) changes in social structures and values. Lastly, the paper will discuss the novelty of this image compared with that of earlier Thai literature and other contemporary books, as well as the factors contributing to this image. Overall, the image of Vietnam in transition is not static but has developed dynamically from the early phase to the later stage of the reform process. Images of a "changing and opening" Vietnam portrayed in Thai contemporary fiction reflect the changes of Vietnam itself, the development of Thai-Vietnamese relations, and the Thai perception of Vietnam under a new historical context.
\end{abstract}

\section{Keywords}

Vietnam - Thai-Vietnamese relationship - Thai contemporary literature 
บทคัดย่อ

ภาพเวียดนามกำลังเปลี่ยนแปลงและเปิดประเทศในหนังสือนิยายร่วมสมัยของไทย

ไทยและเวียดนามเป็นสองประเทศที่มีความเกี่ยวข้องสัมพันธ์กันมายาวนาน จึงมีงานเขียนของไทย เกี่ยวกับเวียดนามมากพอสมควร ทั้งหนังสือวิชาการ เอกสารทางประวัติศาสตร์ หนังสือประเภท สารคดีท่องเที่ยว นวนิยายและเรื่องสั้น บทความนี้มุ่งศึกษาหนังสือประเภทนิยายร่วมสมัยของไทย ที่นำเสนอภาพลักษณ์อันใหม่และโดดเด่นของเวียดนามในการรับรู้ของคนไทย นั่นคือภาพเวียดนาม กำลังเปลี่ยนแปลงและเปิดประเทศ ในการนำเสนออันดับแรก บทความให้ข้อมูลเชิงประวัติศาสตร์ เกี่ยวกับการปฏิรูปของเวียดนามยุคหลัง ค.ศ. 1986 จากนั้นเป็นการวิเคราะห์ตัวบทที่นำเสนอภาพ ของเวียดนามในช่วงการเปลี่ยนแปลงและเปิดประเทศใน 4 มิติได้แก่ $(1)$ การเปลี่ยนแปลงทาง กายภาพของเมืองและความเจริญทางเศรษฐกิจ, $(2)$ การเปลี่ยนแปลงในวิถีชีวิตและประเพณี, $(3)$ การเปิดกว้างของทัศนคติทางการเมืองและความสัมพันธ์ระหว่างประเทศ และ (4) การเปลี่ยนแปลง ทางโครงสร้างสังคมและค่านิยม นอกจากนี้ ในท้ายบทความมีการอภิปรายเปรียบเทียบภาพเวียดนาม ยุคการเปลี่ยนแปลงกับภาพเวียดนามในการรับรู้ของคนไทยในอดีต และภาพเวียดนามในหนังสือ ร่วมสมัยประเภทอื่น ตลอดจนปัจจัยที่ทำให้เกิดความเปลี่ยนแปลงของภาพเวียดนาม โดยภาพ เวียดนามยุคการเปลี่ยนแปลงนี้ไม่ใช่ภาพนิ่งแต่มีความเป็นพลวัตจากระยะแรกถึงระยะหลังของ การปฏิรูป ภาพเวียดนามกำลังเปลี่ยนแปลงและเปิดประเทศในหนังสือประเภทนิยายร่วมสมัยของ ไทย สะท้อนให้เห็นความเปลี่ยนแปลงของประเทศเวียดนามเอง การพัฒนาของความสัมพันธ์ไทยเวียดนามซึ่งเป็นไปในทางที่ดีขึ้น และการปรับความเข้าใจพร้อมการรับรู้ของคนไทยให้สอดคล้อง กับความเป็นจริงของเวียดนามในยุคใหม่

\section{Introduction 1}

Recently Thai society has been revising its awareness and understanding of neighbouring countries. Many scholars point out that Thai mainstream academics and media have for a long time held biased and negative attitudes towards nearby countries due to a sense of Thai nationalism. The influence of sources of Western origin has also resulted in many myths and stereotypes. Today, improved diplomatic relations in the region, greater acceptance of pluralism, diversified sources of information, and new platforms for expression create opportunities for new dimensions in area studies, and allow for other perspectives to be voiced and heard.

Vietnam is an important neighbouring country of Thailand, sharing no common border but having frequent and dynamic contact due to close proximity. The relationship and mutual exchanges between Thailand and Vietnam

1 This article is part of the author's thesis on "The Construction of Images of Vietnam in Thai Contemporary Writings". 
throughout history have seen many ups and downs. Vietnam used to be considered an enemy of Thailand. What Thai people knew about Vietnam for a long time were mainly images of the Vietnam War, Vietnamese refugees in Thailand, and distorted images of communists. Accordingly, feelings towards Vietnam were often characterized by ignorance, indifference or hatred, misunderstanding, fear, or, at best, pity and mercy. Today the attitude of Thai people has turned into understanding, interest, and respect as much more comprehensive representations of Vietnam have emerged.

This paper will present a new and outstanding image of Vietnam in the Thai perception - an "opening and changing" country - from factual data and from literary textual analysis. First, it will provide readers with the socio-historical background of the Renovation Era of Vietnam after 1986. Next, the main part will explain how the image of an "opening and changing" Vietnam is portrayed through textual analysis of Thai contemporary fiction about Vietnam. The image of Vietnam in transition is not static but has developed dynamically from the early phase to later stages of the reform process. Last but not least, the paper will discuss the novelty of this image compared with that of earlier Thai literature and other contemporary books, as well as the factors contributing to this portrayal.

\section{“Opening and changing” Vietnam or its Renovation Process}

This paper uses the term "opening and changing" Vietnam to refer to Vietnam in its transition from the post-Cold War era to globalization. After the end of the Vietnam War and the country's unification in 1975, Vietnam had an underdeveloped economy which resulted from the war, a trade embargo and a centrally-planned economic model. Evolving international situations, isolation, backwardness, and inflationary crises forced Vietnamese leaders to start a kind of "new thinking" and carry out reforms beginning in the late 1970s. The transition process, however, was marked by the momentous Sixth Party Congress in 1986, in which the Communist Party of Vietnam (VCP) declared its "Doi Moi" policy. "Doi Moi", which literally means "to change into newness" and is officially translated "Renovation", refers to the shift from a command economy to a market economy. It involved a series of large-scale reforms such as leadership reforms, decentralization of decision making, legal framework and parliamentary development, macroeconomic management, opening for different ownerships, boosting production, etc.

The renovation brought about dramatic changes in Vietnam. Annual gross domestic product (GDP) grew in excess of 9 percent in the mid-199os, and 
remained in the high range of $5.5-7.5$ percent during the 2000s (the World Bank Data 2018). More crucially, Vietnam's economic structure shifted from the equitisation of state-owned enterprises to joint stock companies and a rapid expansion of private firms. The issuance of the Enterprise Law in 2000, followed by decrees promoting SMEs, was "seen as official recognition of the importance of the private sector". The number of new enterprise registrations rose from an estimated 40,000 during the 1990s to 200,000 by 2006 (Kokko 2008, 16-17).

Vietnam's opening to the world started in 1989 , when the new thinking expanded to the larger sphere of international relations, diplomacy and foreign trade. The country's decision to withdraw all troops from Cambodia that year cleared the biggest obstacle for acceptance on the global stage and the realization of the Doi Moi process (Thayer 1999). Vietnam's ASEAN membership and normalization of relation with the US in 1995 are milestones in the process of opening up. Vietnam's application for World Trade Organisation (WTO) membership in the same year, only days after its establishment, expressed the country's full determination to integrate more deeply into the world economy (Elliot 2012, 216). Foreign direct investment (FDI) inflow mounted after the above events, from only 4 thousand USD in 1989 to 2.4 billion in 1996 before reaching the incredible number of nearly 9.58 billion USD in 2008 (World Bank Data 2018). One important accomplishment was the creation of a new image of Vietnam: most foreign observers being asked in 1999-200o felt that "Vietnam was becoming more open, cooperative, and at ease with its regional environment" (Elliot 2012, 161).

However, the prolonged process of renovation in Vietnam was never smooth. The inconsistency did not lie in overall policy but in detailed implementation, like Vylder $(1995,37)$ commented - "few people in Vietnam [would] question the need for reform; the issue [was] how, rather than if, and the pace, rather than the general directions". After preliminary success in stabilizing the socioeconomic situation, the reforms "caused deep ideological differences to emerge within the VCP leadership" in early party congresses, slowing the development considerably during the period 1996-1999, which was called the "uncertain transition" (Elliot 2012, 161; Ratliff 2008, 13-14).

In reality, various problems became increasingly complex over time, mainly due to the state's inconsistent application of policies and intense involvement in the economy, according to almost all scholars writing about Doi Moi. Even now the state remains the dominant actor, maintaining substantial ownership shares in most equitised firms (about 70 percent) (Kokko 2008, 14). In spite of nearly two decades of market-oriented reform, more than 55 percent of Vietnam's total investments are channeled through the state sector, creating an 
environment of severely limited accountability and high risks for corruption (Kokko 2008, 33). Moreover, by the end of the 199os, private domestic firms were at best accepted in non-strategic sectors, but there was no direct support regarding business licenses, foreign trade rights, land, and credit - all areas where state-owned enterprises had various privileges. In this environment, the strong determination to acquire more autonomy in the first place cooled down to satisfaction with partial reform because it was "generally considered too risky" to step "from stable state ownership to an uncertain future in the private sector" (Kokko 2008, 12).

In socio-cultural terms, Vietnam holds the standpoint of being open but not totally. The policy to build "an advanced culture with strong national identity" announced by the Party Central Committee in 1998 has been adhered to ever since. To elaborate on the above slogan, the party resolution points out the need to link culture with economic development and all aspects of social life; to develop and assimilate the values and dignity of Vietnamese identity; to safeguard and promote national identity in the context of industrialisation, modernisation and international integration; to foster cultural values such as healthy ideals, lifestyles, spiritual capacity, virtues and Vietnamese cultural identity amongst youngsters, students and pupils; to invest in the preservation and restoration of revolutionary heritage sites, tangible and intangible heritage elements in harmony with the development of the tourism industry, volunteerism and self-management amongst people in building cultural life, etc. (Bui 2013). Regarding the specific goal of integration, Vietnam tries to introduce its culture to the world, encourages exchange and learning of international values but emphasizes "hoa nhap, khong hoa tan", i.e. 'integration' or joining the global system but not 'assimilation' or not being 'dissolved/ transformed' by it (Pham 2009).

\section{Turning Point in Thai-Vietnamese Relationship}

As mentioned earlier, the Doi Moi process has brought Vietnam closer to the world, including its neighbours in Southeast Asia. This has also meant a turning point in Thai-Vietnamese relations.

The relationship and mutual exchanges between Thailand and Vietnam throughout history are rather complicated and multi-dimensional. This long process is thought to date back to early trading routes across territories in Siam and Vietnam. Vietnamese people also headed to Ayuthaya as a land for immigration in the $17^{\text {th }}$ and the beginning of the $18^{\text {th }}$ centuries, due to political unrest and a lack of religious freedom in their home country. Despite being small 
in scale, such trading activities and immigration show the long-lasting course of exchanges between Thailand and Vietnam. In later periods, Thai chronicles, or phongsawadan, recorded many active relations in the Early Rattanakosin Era between the two royal courts - the Chakri Dynasty of Siam and the Nguyen Dynasty of Vietnam for a duration of about go years (1776-1867) spanning the reigns of kings Rama I - v. King Rama I provided Prince Nguyen Anh (King Gia Long later) with shelter in Siam, and later weapons upon his return to Vietnam. Therefore, under the reign of King Gia Long, Vietnam sent tributes and kept regular and positive contact with Siam. During the reign of King Rama II, relations between Siam and Vietnam worsened and in the reign of King Rama III, turned into frequent hostilities for greater control over Cambodian territory and politics. Despite official conflict between the two sides' courts and militaries, Vietnamese migrants, both Catholic and Buddhist, were welcome to settle and practice their religion in Siam from the Thonburi period until the reign of King Rama v.

The era of modernization and Western colonialism led Thailand and Vietnam along completely different paths of nation-state building. The former headed for capitalistic, pro-western modernization; whereas, the later shifted from feudalism to socialist nationalism and fought against the French for revolution and independence. The northeast region of Siam was considered a haven for Indochinese Vietnamese escaping hardship under colonial rule, and a base for nationalist activists to recover and nurture their secret movements. The Pridi government was sympathetic to the Vietnamese fight against French colonizers and allowed free passage for Vietnamese refugee revolutionaries (Poole 1970). They also received protection and help from the people and local authorities of the Northeast. However, the subsequent Phibun and other military governments during the anti-communist era implemented strict, suppressive measures on refugees. During the Vietnam War, Hanoi's aid to Northeastern Thai dissidents and the Thai government's support for US military operations and its later decision to send troops to South Vietnam brought Thailand and North Vietnam to sharp opposition (Poole 1970, Theeravit 2003). Hatred and fear of communists was high in Thai society, driven by pressure from the Vietnam War, Thai leftist movements, and government propaganda. Nevertheless, the rivalry in terms of ideology and politics did not prevent human sympathy and friendship. Notes and memoirs by Vietnamese refugees told many stories about the generous help and protection they received from Thai officers and commoners, as well as the bond between Vietnamese and Thai in northeastern provinces (Rato 2011). Accordingly, Thai people's knowledge and understanding of Vietnam were very much based on hearsay about the Vietnam War, Vietnamese communists, and their contacts with Vietnamese refugees. 
Thai-Vietnamese tensions eased with the end of the Vietnam War. Thirty years since then has witnessed steady development of the relationship. The turning point was the settlement of the Kampuchean dispute in 1991, as well as the adoption by both governments of foreign policies aimed at meeting the needs of economic development. Vietnam declared the Doi moi policy and an open diplomatic orientation whereby the country sought to make friends with all other countries in the world. Meanwhile, Chatchai Chunhawan's government also adopted a new approach to Indochina: "turning battle fields into market places". Bilateral relations warmed further with Thailand's support for Vietnam to join the Association of Southeast Asian Nations in 1995 (Theeravit 2003). Regionalisation promoted connectivity among mainland Southeast Asian countries such as the East-West corridor project, increasing lowcost flights, etc., which in turn boosted travel, trade and exchanges among the countries. Government-to-government and people-to-people relationships and cooperation were enhanced a great deal as a strategic partnership was announced in 2013. After 2007, when the ASEAN nations collectively agreed to shorten the timeline to establish the ASEAN Community from 2020 to 2015, the interest of Thai people in neighbouring countries, including Vietnam, surged. The next part of this article attempts to analyse how this new and interesting image of Vietnam has been portrayed in Thai contemporary fiction.

Image of an "Opening and Changing" Vietnam in Thai Contemporary Fiction

The decade of the 1990s, as noted previously, marked a new page in the regional atmosphere and Thai-Vietnamese relations. In this context, Thai people's image of Vietnam from diplomatic, economic and socio-cultural dimensions also changed. There was an active search for more knowledge about neighbouring countries, including Vietnam, as the old perspectives of previous eras were reexamined. Almost all the books about Vietnam published in this time, whether they are travel writings, novels or short stories, are the result of their authors' trip or stay in Vietnam. Thai literature, thus, paints a more realistic picture, attesting to more comprehensive knowledge of Vietnam and Vietnamese people and thus distinguishing it from works about Vietnam in the past.

In my extensive search for Thai books about Vietnam in the contemporary period since the 1990s, I have found a total of 20. Most of them, 16 to be exact, are travelogues, telling the writers' experiences in and opinions about Vietnam as tourists. However, according to Moeller (2011), who studied "Thai 
Attitude towards Vietnam as shown in Contemporary Travel Writing", few of the authors of these travelogues had in-depth contact with Vietnamese people. Besides, many factors such as varying degrees of openness to Vietnam, different travel styles and itineraries "are of extreme relevance and can influence attitudes both positively and negatively" (Moeller 2011, 81). In contrast, fiction has superior strengths, possessing literary means such as plot, characters, and conversations to describe in more detail human life and feelings as well as to reflect more complicated social features and deeper analysis. Unfortunately, the portrayal of Vietnam from a Thai literary perspective has not been much noticed so far.

Therefore, this paper aims to study four Thai contemporary works of fiction about Vietnam: (1) Khwam lap thi Sapa (Secret at Sapa), (2) Mai mi thoe... mai mi tawan (There is no sunshine without you) by Thatsanawadi; (3) Vietnam tam lamphang (Alone in Vietnam) by Khachonrit Raksa, and (4) Rak nai man fon (Love in the rain) by Praphatson Sevikul. The first two books are both set in Hanoi around 2000; the former is a short novel while the latter is a collection of short stories. They were written from the real experience of the same author, Thatsanawadi, during his posting in Hanoi as a Thai language teacher to Vietnamese students. In his portrayal of Vietnam after living and working there for one year, Vietnamese society, with its underlying caution and strong traditional style of living, is shown as not very open despite the introduction of reform policies. The other two novels, Vietnam tam lamphang (Alone in Vietnam) by Khachonrit Raksa and Raknai man fon (Love in the rain) by Praphatson Sevikul, were written some 10 years after the books by Thatsanawadi, the former in 2010 and the later in 2012. Their main characters are Thai girls travelling to Vietnam: in the former, Jam wants a break from her problematic personal life and finds inner peace in Tam Dao; Rain, in the latter novel, travels with no expectations but becomes very interested in Vietnam. The books bring us a more updated image of Vietnam - a more materialistic society, more open in its views and attitude toward change and integrity, while also showing evidence of deeper social conflicts. The four works of fiction portray Vietnam in the process of changing and opening up in the following aspects:

\subsection{Physical Changes in Landscape, Cityscape and Economy}

Physical changes caused by development and urbanisation are the most obvious. The picture of Vietnam in the early years was as a relatively backward, peaceful country. In Thatsanawadi's books, Hanoi, the capital, is like a small town while other nearby provinces such as Bac Giang or Son La are rural villages with rice fields, vegetable gardens, rivers, and hard-working farmers. Even in the city, people still travel by bicycle and do their shopping at fresh markets. 
Children's toys are as simple as animals made from leaves. Some signs of modernity like luxurious shops are mentioned but very few.

The tranquil quiet image of Vietnam changes a great deal due to modernity and economic development. Bao An, the main character of Praphatson Sevikul's Raknai man fon (Love in the rain), a Vietnamese tour guide provides many statistics as proof of current economic changes and future plans to modernise Vietnam, such as the construction of airports, hotels, tourist attractions and other facilities to meet the demands of the booming tourism sector. The $2010 \mathrm{~s}$ was a time when travel to Vietnam became very easy; Vietnam became an attractive destination to world travelers and Thai tourists, in groups or as solo travelers, like Jam and Rain. Hanoi in the girls' eyes is no longer a small peaceful town; the large number of people, shops, and motorbikes constitute the image of a rapidly developing city.

A negative aspect of this "changing Vietnam" is money-driven tourism services, especially transportation and shopping. Khachonrit Raksa illustrates vividly how Jam in Vietnam tam lamphang (Alone in Vietnam) gets lost in Hanoi among the noise and traffic from street stalls, vendors and strangers. Jam feels afraid that she will be taken advantage of while shopping. She quickly walks past the shops, remarking on the vendors who eye her like prey. What adds to her fear and insecurity is Hanoi's chaotic transportation system: street traffic moves without respect for rules, and drivers sound their horns relentlessly. Bus drivers drive carelessly, turning or switching lanes suddenly, and picking up many more passengers than there are seats. This is a quite popular impression of Vietnam for not only Jam but for many Thai travellers, who are used to quieter and more regulated public spaces. It confirms the typical image of a newly opening country, a mixture of the exotic and the chaotic, with materialistic people trying to make as much profit from tourists as possible.

In addition, urbanization has created an apparent gap between urban and rural areas in Vietnam. In Vietnam tam lamphang (Alone in Vietnam), a crowded, bustling Hanoi is contrasted with Tam Dao, where Jam goes to seek peace. Stressed from urban centers like Bangkok and Hanoi, Jam finds calm and serenity in a beautiful natural setting and among the shy, innocent people of this small town on the mountain, with no trace of modernity or urbanization. In Raknai man fon (Love in the rain), there are differences between Hanoi and the nearby province of Bac Ninh, or between the old areas and newly urbanized centers in one city itself. Even provincial rural villages are faced with expanding urbanization. Visiting Bac Ninh, Rain notices the contrast between the two sides of a road: just a turn of the car brings them from a village "of the old days some hundred years ago" - she notes (Sevikul 2012, 56) - to a big road with urbanized flats and shops. 


\subsection{Changes in Lifestyle and Traditions}

Changes do not occur only to physical aspects of Vietnam but also to the broad scope of social life, like lifestyle and traditions.

In the early stages of the reform period, Vietnamese society was still very much community-oriented. Thatsanawadi observed this in his daily life during one year in Vietnam. The bicycle-keeper and vendors near his apartment were friendly and liked talking with him. When the teacher visited his student's house, he was warmly welcomed by the whole family, relatives and even neighbours. Vietnamese students were described as having a very simple lifestyle in general. They focused on their studies, strictly complied with the ideology and philosophy they were taught, and tried their best to reach their targets for a better future. They spent their free time taking care of the expat teacher, or doing activities like cooking, camping, singing, and climbing mountains. They were born in an age when Vietnam was embarking on a market economy, but exciting new forms of modern entertainment were not popular or affordable for the majority of Vietnamese. Overall, they still followed traditions and social conventions - respecting and obeying their teachers, giving priority to duties and authorised orders.

Furthermore, many people still clung to traditional living and old regulations or customs, like Uncle Dinh in Raknaiman fon (Love in the rain). After the war and especially during the economic reform period, instead of moving forward like many other people, Uncle Dinh spends his life looking back. His favourite activities include talking about the past, going to quiet places, and looking at old houses. He teaches Bao An to feel proud of national history, and to respect those who sacrificed in the wars. Thus, Uncle Dinh represents a Vietnamese generation who has lived through the war, is full of nationalist pride for the country's glorious history, and tries to transfer this spirit to new generations.

Praphatson Sevikul, on the other hand, points out the noticeable differences that modernity sooner or later causes to Vietnamese traditions and the life of Vietnamese people. Vietnam's long history and culture are portrayed through tales of the Sword Lake, special Hanoi dishes like "pho" or "cha ca", the custom of people drinking tea and sharing their lives with friends, Temple Lim in Bac Ninh, the custom of singing "Quan Ho", and the village producing the delicacy "tuong" sauce. However, almost every time a traditional feature of Vietnam is mentioned, there is the suggestion that they are disappearing and will soon be replaced by modern things. Bao An foresees that when roads are newly built or extended, people in Hanoi might not go out to drink tea at leisure and talk with each other like at present. Instead, they will go to coffee shops or stay isolated in modern, high-rise condominiums. He also gives 
examples of new life styles of Vietnamese teenagers, such as a more hurried life spent on Internet-connected mobile phones, and their preference for rock and rap music instead of old folk songs or country music.

\subsection{Changes in Social Structures and Values}

The new historical period and integrating economy have brought about changes in the deep layers of Vietnamese social structures and values. The first obvious change is the appearance of a new group of materialist people. They include a few people who experienced the war and now use this experience to acquire fame and other benefits, and a new generation born after the war, who are ambitious and excited by wealth and modernity.

The representative of the first type is Doctor Van in Rak nai man fon (Love in the rain), an ambitious, selfish man who tries to get a high position and all the benefits associated with it, ignoring social criticism of his lack of morals and professional ethics. He is condemned for his greed and remorselessness: "That place [Doctor Van's clinic] only gives treatment to rich people. They don't care about poor patients like us... Doctors in the old days cared about their patients first, but doctors nowadays like Doctor Van prioritize money over everything else" (Sevikul 2012, 59). Doctor Van, in return, accuses Nha Ninh's parents, who are loyal to their set of values - respect for the law, trust in justice, and a rejection of the influence of money, of being conservative and preventing social development: "They should all die so that Vietnam can be more developed. Those who stick to Confucian teachings and class revolution are obstacles to social development" (Sevikul 2012, 165-166). Accordingly, Doctor Van represents those materialists who run after new opportunities and benefits, and cast aside everything that stands in their way.

His son, Van Viet, is typical of young materialists in Vietnamese society. Born into a rich family, he is allowed to do everything he wants, and all his material needs are immediately met. In the eyes of Nha Ninh's family, Van Viet is only interested in having fun like driving motorbikes or flirting with girls, and pays no attention to serious things. His life target is wealth and personal entertainment. A more negative representation of materialism is the son in the short story titled "Mother's drops of sweat" in Thatsanawadi's collection $K h$ wam lap thi Sapa (Secret at Sapa). Having received a higher education, he wants to have a better life, denying his poor background and adopting a materialistic lifestyle. He spends more money than his mother, a vegetable vendor, can afford; he keeps asking for a new bicycle and fashionable clothes. Worse than that, he is an ugly picture of merciless, selfish young people who care only about themselves. When he sees some street vendors being arrested by the police, not knowing that his mother is among them, he comments: "Those 
preventing development should all be swept away". Apparently, social conflict and generational contrast with respect to materialism are shown as increasing in Vietnamese society.

Apart from the new desire for wealth and material comfort, there appear new social values, especially individual liberation and development. Bao An in Rak nai man fon (Love in the rain), as a representative of the new generation with new ways of thinking and new values, supports the idea of personal fulfillment. He does not think it is everyone's duty to work for the state sector. Each individual has the right to develop himself to the full and to follow his own aspirations, which in the end will advance the country's development.

Van Viet, another teenager in this story, also presents a new view of success and happiness, and the way to achieve them. While Nha Ninh, an introverted girl, always obeys her parents, studies hard, dislikes hanging around and is satisfied with her simple life, Van Viet tries to persuade her of the importance of youth's being alert to new situations and actively searching for new opportunities:

"Vietnam these days is no longer the same as Vietnam in the past... Now our country is opening its doors to welcome foreign trade, investment and tourism. If you only stay in your house, you cannot catch up with people, you will miss the chance to get rich, and your life will be as quiet and boring as the old generation" (Sevikul 2012, 99).

Contributing to the social changes in Vietnam are changing values in child raising and education. In terms of raising and educating children, Nha Ninh's parents are typical of many family-oriented and protective Vietnamese parents, who plan the future path for their children to follow. They expect their daughter to obey and to marry a good boyfriend in order to have a "stable" life. In contrast, Van Viet's parents fulfill all of their son's wishes and allow him to do what he wants. With regard to formal education, Van Viet criticises Vietnamese schools, which have taught the same outdated knowledge for many generations. When Nha Ninh defends the necessity of learning basic theories, Van Viet argues that experience is more necessary; one needs to open one's self to the larger world. Moreover, traditional teaching methods are boring and can no longer meet the requirements of reality. His complaint is in line with Ratliff $(2008,32)$, who wrote that "Universities and institutes [in Vietnam] have lacked close linkages with the business world; training quality and efficiency have been poor; teaching and learning methods are out of date; resources have been limited, and resource utilization has been inefficient." 
One more remarkable change concerns feminism. Female characters in books of the 20oos are traditional images of Vietnamese womanhood. The mother in "Mother's drops of sweat" in Thatsanawadi's collection Khwam lap thi Sapa (Secret at Sapa) are like a majority of women of her time - working laboriously in a fight against poverty and hardship their whole life, and wholeheartedly sacrificing her own comfort for her son's well-being and his future. Young girls in other short stories as well as the novel Mai mi thoe... mai mi tawan (There is no sunshine without you) are reserved and caring, in keeping with the popular image of romantic Vietnamese ladies. Ma-fuang is the most beautiful and talented among them but has an unhappy love with her Thai teacher. Her decision to let go of this love shows that Vietnamese girls in the past were not free and independent to live and love for themselves; their lives were still very much controlled by more powerful people, by social status and duty, and by political ideology and organization.

As time passes, girls are freer to pursue their personal plans and feelings. If all the other characters in Raknai man fon (Love in the rain) have a clear preference for either the modern or the traditional from the beginning, Nha Ninh is the only one who experiences a dramatic change in her mindset. She used to live a simple life without any ambition: going to university every day, staying at home in her free time rather than hanging around, obeying her parents, waiting for her boyfriend and a future with him. When she realizes that her boyfriend does not love her as much as before, she decides to go abroad for further study, surprising her parents a great deal. The maturity in Nha Ninh's character shows great potential to overcome life crises and adjust to changing situations. It also reflects important development in young Vietnamese women in the new era: Now they are aware of their value and are more independent - they have the right to choose their own way of life and no longer let parents choose their marriage partner. If readers compare Nha Ninh with Ma-fuang in Mai mi thoe... mai mi tawan (There is no sunshine without you), this is big progress for Vietnamese women.

\subsection{Opening Views regarding Politics and International Relations}

The fundamental change that contributed to the aforementioned changes in Vietnam concerned its opening views towards domestic development and international relations.

Bao An in Rak nai man fon (Love in the rain) plays the role of the spokesman of Vietnam in its important adjustment of political policies and, hence, reflects very clearly the Renovation process of Vietnam (as reviewed in the previous section). He views the old way of state-centered governing as no longer suited 
to the current situation and in need of urgent reforms. He believes in opening policies, explaining that economic development and political security can go together, and Vietnam cannot use an ideological frame to block or limit the growth of its economy. He respects pluralism, claiming that it is not necessary to follow only one way to reach the target. He chooses not to work as a governmental official but to be a tour guide since he is aware of the role of the private sector as an important driver of the economy. Vietnam's Renovation Era is a "two-directional process" - "grassroots upwards" and "central leadership downwards" (Vu 1995, 18), in which private domestic firms push the country's total output, exports, and employment. In other words, Bao An's open worldview represents people who support reform policies.

Nevertheless, as the previous section on socio-historical background has remarked, reforms bring different reactions and attitudes. The renovation that the books reflect is not a sudden change but a difficult process leading to the adoption of more ideological openness. Tan, Bao An's friend, represents those who strictly follow and protect their political ideology. Tan requests frequent attendance at CPV party meetings; he thinks that one needs to fulfill the tasks assigned by the nation and the party and that the party's promotion is the most honorable way to ascend the social ladder. The conversations between the two friends often end in conflict between duty to nation and personal fulfillment, between rigid political ideology and economic reform.

To solve the conflict, Vietnam attempts to balance between the old and the new, between reformation and preservation. Bao An's personality consists of both sides - love for ideology and a pro-reform attitude. He is nostalgic and regrets the loss of old values sometimes, but most of the time he is realistic about unavoidable changes:

"No one can resist the trend of changes... If we don't change ourselves we will be left behind. All we can do is to be aware of the valuable things we have such as history, arts and culture, living style, and preserve them as our roots - inseparable from our present and future" (Sevikul 2012, 94).

In other words, Vietnam accepts new challenges and considers opening and changing a matter of course. Moreover, Bao An proves that Vietnam is making a serious effort and has its own way to avoid conflict: "We never think to change the world. We use another way - changing people. This method is slow and might take time from one generation to another. But in the end, we will have a new world where everyone can live together in harmony" (Sevikul 2012, 52).

Regarding international integrity, Vietnam shows an opening attitude. In the early phase, conservative thinking dominates. Mr. Hoang, the Vietnamese 
teacher in Mai mi thoe... mai mi tawan (There is no sunshine without you), strongly held to regulations and conventions, refusing changes and novelty. He did not agree to include new content in the Thai language syllabus, insisting on following his outdated textbook which limited students' language development. He was unhappy to see the students love the Thai teacher more than him. After the Thai teacher travelled to Son La Province with the students, Mr. Hoang accused him of taking part in suspicious activities with ethnic minorities and loving students unequally. Mr. Hoang even called the police to interrogate him and forced the students to distance themselves from him. On the surface, Mr. Hoang still talked with the Thai teacher and inquired after his well-being; but behind his back, Mr. Hoang tried to control all the teaching and personal activities of the Thai teacher.

Mr. Hoang's character is a hint of Vietnamese authority at that time when there was a gap between policy and its implementation. While Vietnam may have introduced diplomatic policies welcoming other countries, it was still very careful and suspicious of foreign elements and foreigners' activities in Vietnam. This is also the reason why the love between the Thai teacher and Ma-fuang, the Vietnamese girl, could not end happily. Since Ma-fuang is an outstanding student, she is a likely recruit for the Communist Party, an important channel for advancement for youth at the time. Members of the Communist Party were not encouraged to marry a foreigner, and if they did, their chance of promotion was slim. Different social status between teacher and student, political rules, and social expectations were insurmountable obstacles to Ma-fuang's love. This portrays Vietnam in its newly reforming phase, opening-up on the surface but deep down, skeptical and conservative. Despite a decade of doi moi policy, Vietnam was still reserved and careful in building relations with countries not from the same ideological system.

Fear and skepticism cannot resist the worldwide trend toward cooperation and integration, however. Signs of Vietnam's opening-up to the outside world can be found in the promising image of Vietnam's new generation - intelligent and eager to learn new things. The appearance of an unpopular language in Vietnam's tertiary education and the students' interest in learning Thai language and culture indicate Vietnam's increasing cooperation with foreign countries, in this case Thailand. The love between Ma-fuang and the Thai teacher is a clear result of widening international exchange and an increasing number of foreigners in Vietnam.

The important shift in Vietnam's perception of itself and the world in its later phase of renovation is reflected in Bao An's talks and friendship with "Rain, a Thai tourist" in Raknai man fon (Love in the rain). Bao An tries to introduce Vietnamese cultural values, and at the same time, affirms his progressive 
thinking about social and economic development. He is open to an exchange of thoughts and views with Rain about developments occurring in Vietnam at the present and about the Vietnamese way of life, which is different from that of Thai people. This confidence and openness are new characteristic of Vietnamese people, not found in earlier works. All of this suggests that Vietnam today is ready to shake hands with other countries, welcomes foreigners, proudly presents itself to the outside world, and looks forward to more open exchanges of information and ideas. When Rain and Bao An part, they promise to keep in touch and nurture their relationship. Vietnam's relations with other countries, in this case Thailand, are portrayed as an equal and open-minded partnership defined by mutual trust and respect.

\section{5}

\section{Conclusion}

This textual analysis of four Thai works of fiction about Vietnam reveals these interesting dimensions of a "changing and opening" Vietnam:

(1) These contemporary works present a new image of Vietnam compared with previous Thai writings about Vietnam such as Phongsawadan, or Thai chronicles of the Early Rattanakosin period (spanning the reigns of King Rama I to IV), and books about Vietnam during the Cold War era like Songkhram Vietnam (The Vietnam War) by M.R. Kukrit Pramoj (1968), Yuon ya le (Vietnamese lullaby) by Lithi Itthipracha (1975), Vietnam, laeo Thai (Vietnam, then Thailand?) by Phan Rakkaeo (1976), or Yuon opphayop (Vietnamese refugees) by Khachatphai Burutsaphat (1978). The image of a "changing and opening" Vietnam is very far from old images of war, refugees, and communists that previously dominated Thai perceptions.

(2) The image of an "opening and changing" Vietnam in these works is also different from the portrayal in other contemporary books or media. They do not discuss Vietnam's transformation only from visible changes with growing cities, booming tourism or indexes of economic development. They do not point to Vietnam's integration into the global world order and its open diplomacy citing the number of new partners or official visits. Readers of these four books reveal deeper changes that shatter Vietnamese core values and norms in both positive and negative ways, such as adapted ideology, a progressive worldview, forgotten customs, ignored professional ethics, awakening women, and an urbanised lifestyle. In its dramatic changes, Vietnam is attempting to balance the old and the new, and overcome social problems linked to reforms.

In addition, the books by Thai writers provide more individual perspectives on the renovation in Vietnam, differing significantly from the perspectives of the state, diplomacy or the media. Looking in depth, readers will see a variety 
of different stories, views, reactions and attitudes towards reform, varying by background and personality of specific characters. This then will give them a fuller understanding of generational conflicts and contrasting ideas within the same generation in Vietnam today. As a result, the image of an "opening and changing" Vietnam is more multi-dimensional, and its transition is a complicated on-going process.

(3) Essential factors in forming a remarkable new image of an opening and changing Vietnam include the reality of Vietnam's own reformation, and warmer Thai-Vietnamese relations since the 199os. Specifically, these writers had first-hand experience of that reality. Thatsanawadi spent one year working in Vietnam; Khachonrit Raksa stayed in Vietnam for a month writing his book; Praphatson Sevikul travelled to Vietnam many times. Their exposure to Vietnam provided insights and understanding. In addition, fiction gives space for vivid, detailed portrayals rather than careless stereotypes based merely on appearances. The lives, characteristics and emotions of characters are more effectively displayed through narration and dialogue, many times from the voices of insiders. Contradictory groups of characters, like those in Raknai man fon (Love in the rain) demonstrate clearly the conflict between two different times and generations, reflecting the complicated course of reforms.

To conclude, this paper has examined the image of a "changing and opening" Vietnam in its transition from post-Cold War to globalization. From Thatsanawadi's books written around 2000 to Khachonrit's and Praphatson's novels of about 2010, Vietnam has changed and grown increasingly open from its first reform stages to its full integration into global affairs. We see various differences in Vietnam: (1) physical changes in landscape, cityscape and economy (2) changes in lifestyle and traditions (3) opening views regarding politics and international relations, and (4) changes in social structures and values. The books, told from the perspectives of individuals, bring Thai readers a more realistic and more complete picture of Vietnam with its increasingly sophisticated, urbanized, and modernized society. This image is very close to the reality of the country today. Last but not least, the new image of Vietnam marks an important step in Thai perceptions of neighbouring countries and indicates the current harmony in Thai-Vietnamese relations, with frequent and deeper contact at all levels.

\section{References}

Bui, Hoai Son. 2013. "Historical Perspective: Cultural Policies and Instruments". In Country Profile: VIET NAM. WORLD CP: International Database of Cultural Policies. http://www.asef.org/images/docs/WorldCP-Asia-Viet\%2oNam\%2oProfile.pdf. 
Burutsaphat, Khachatphai. 1978. Yuon Opphayop (Vietnamese Refugees). Bangkok: Duangkamol.

Elliot, David W. P. 2012. Changing Worlds: Vietnam's Transition from Cold War to Globalization. Oxford University Press.

Itthipracha, Lithi. 1975. Yuon ya le (Vietnamese Lullaby). Bangkok: Witthayawut.

Kokko, Ari, ed. 2008. Vietnam: 20 Years of Doi Moi. Hanoi: Vietnam Academy of Social Sciences \& The Gioi Publishers.

Moeller, David J. 2011. "Thai Attitude towards Vietnam as shown in Contemporary Travel Writing." Master's Thesis, Chulalongkorn University.

Pham, Duy Duc. 2009. "The viewpoints of Vietnamese Communist Party about Constructing and Developing an Advanced Culture with Strong National Identity." In Developing Vietnamese Culture during 2011-2020 - Methodology Issues. Hanoi: National Politics. (In Vietnamese)

Poole, Perter A. 1970. The Vietnamese in Thailand, a Historical Perspective. Ithaca: Cornell University Press.

Pramoj, Kukrit M.R. 2014 (1 $1^{\text {st }}$ published in 1968). Songkhram Vietnam (Vietnam War). Nonthaburi: Dok-ya20oo. (In Thai)

Rato, Montira. 2011. "Prathet Thai nai thatsana le khwam song-cham khong Viet Kieu: phap sa-thon khwam sam-phan ra-dap prachachon" (Thailand in the Views and Memories of Viet Kieu: Reflection of people-people relationship).Journal of the Historical Society 33: 57-78. Bangkok: The Historical Society. (In Thai)

Rakkaeo, Phan. 1976. Vietnam laeo Thai (Vietnam, then Thai?). Bangkok: Praphansan. (In Thai)

Raksa, Khachonrit. 2010. Vietnam Tam Lamphang (Alone in Vietnam). Bangkok: Ban nangsue.

Ratliff, William. 2008. Vietnam Rising: Culture and Change in Asia's Tiger Cub. California: The Independent Institute.

Sevikul, Praphatson. 2012. Rak nai man fon (Love in the rain). Bangkok: Nanmee Books. Thatsanawadi. 2003. Khwam lap thi Sapa (Secret at Sapa). Bangkok: Nam wan. (In Thai) Thatsanawadi. 2011, $2^{\text {nd }}$ edition. Mai mi tho mai mi tawan (There is no sunshine without you). Mahasarakham: Pongbai.

Thayer, Carlyle A. 1999. "Vietnamese Foreign Policy: Multilateralism and the Threat of Peaceful Evolution." In Vietnamese Foreign Policy in Transition, edited by Carlyle A. Thayer and Ramses Amer, 1-24. Singapore: Institute of Southeast Asia Studies.

The World Bank Data. 2018. "Foreign direct investment, net inflows (BoP, current US\$)/ Vietnam.” https://data.worldbank.org/indicator/BX.KLT.DINV.CD.WD? locations=VN.

Theeravit, Khien. 2003. "The Development of Thai-Vietnamese Political Relations." In Twenty-five Years of Thai-Vietnamese Relationship, edited by Thanyathip Sripana, 
Theera Nuchpiam and Pham DucThanh, 1-17. Bangkok: Institute of Asian Studies, Chulalongkorn University.

Vu, Tuan Anh. 1995. "Economic Policy Reforms: An Introductory Overview." In Vietnam in a Changing World, edited by Irene Norlund, Carolyn L. Gates and Vu Cao Dam, 17-30. Nordic Institute of Asian Studies \& Curzon Press.

Vylder, Stefan de. 1995. "State and Market in Vietnam: Some Issues for an Economy in Transitions." In Vietnam in a Changing World, edited by Irene Norlund, Carolyn L. Gates and Vu Cao Dam, 31-50. Nordic Institute of Asian Studies \& Curzon Press. 